\title{
The Effect of Foreign Portfolio Equity Purchases on Security Returns in Kenya: Evidence from NSE Listed Financial Institutions
}

\author{
Loice Koskei $^{1}$ \\ ${ }^{1}$ School of Business \& Economics, Africa International University, Nairobi, Kenya \\ Correspondence: Loice Koskei, P.O. Box 1670-30100, Eldoret, Kenya. Tel: 254-721-799-266. E-mail: \\ loikosy@yahoo.com
}

Received: March 3, 2017

Accepted: March 20, 2017

Online Published: March 25, 2017

doi:10.5539/ijef.v9n4p202

URL: https://doi.org/10.5539/ijef.v9n4p202

\begin{abstract}
Foreign portfolio inflows increase the liquidity and the volume of finance available for financial institutions. At the same time, as foreign portfolio inflows finances in part the capital requirements of local companies, it can also increase the competitiveness of these companies. A huge surge of the inflows can be very inflationary because this forces the Central Bank of Kenya to expand the country's monetary base by releasing counterpart domestic currency which eventually feeds into the inflationary process. The main aim of this study was to find out the effect of international portfolio equity purchases on security returns of listed financial institutions in Kenya. The study population was 21 financial institutions listed on the Nairobi Securities Exchange. Using purposive sampling technique the study concentrated on 14 financial institutions. The research design of the study was causal as it is concerned more with understanding the connection between cause and effect relationships. The study adopted panel data regression using the Ordinary Least Squares (OLS) method where the data included time series and cross-sectional. A unit root test was carried in this study to examine stationarity of variables because it used panel data which combined both cross-sectional and time series information. Panel estimation results indicated that international portfolio equity purchases have no effect on stock returns of listed financial institutions in Kenya. The study recommended implementation of regulations and policies that would attract foreign portfolio equity inflows in financial institutions.
\end{abstract}

Keywords: international portfolio equity purchases, stock returns, financial institutions, Nairobi securities exchange, Kenya

\section{Introduction}

The large net capital flows of the 1990s and the concomitant increase in the role of international investors in developing countries led many to reconsider the benefits and costs of net portfolio inflows with some urgency. The Mexico crisis has been an important cause of this reconsideration. It led many to worry about the stability of portfolio investments. Contrasting the Mexico crisis to the debt crisis of the early 1980s highlights why sudden changes in portfolio flows might be a source of concerns. There were few key players in developed countries during the debt crisis, their claims were illiquid, and consequently had strong incentives to negotiate solutions with the developed countries. Coordination among portfolio investors was impossible during the Mexico crisis. Even though collectively investors might have been better off in committing funding to the Mexican government to resolve the crisis, individually each investor was better off by selling out and could do so quickly because the investor was holding liquid securities. Some economists have therefore argued that financing a country's growth through portfolio investment can expose countries to sudden inflows and outflows that can destabilize sound economies, force them into dramatic macroeconomic adjustments, and cause havoc in their securities markets (Ren, 1997).

Financial liberalization in Kenya in 1990's was accompanied by stock market liberalization. This resulted in the opening of the domestic stock market to foreign investors. This was driven by the need to integrate and make the market more vibrant leading to increased foreign portfolio inflows. The level of foreign trade picked up in Kenya after restrictions on inward portfolio investments were lifted in January 1995. Overall, the total foreign turnover increased over time from a low of Ksh. 695 million in 1996 to the highest of Ksh. 160,213 million by the end of 2013 (CMA, 2013).

The complete liberalization of offshore borrowing in Kenya was implemented in May 1994, while some 
restrictions on inward portfolio investment were lifted in January 1995, therefore allowing participation of foreign investors in the Nairobi Securities Exchange trading under guided policy. Foreign investors were permitted up to $20 \%$ of equity for inward portfolio investment that is aggregate of each stock and a $2.5 \%$ limit for individual investors. This was revised upwards in July 1995 so that the individual investor limit was increased to 5\% while the aggregate was set at 40\%. On 26 July 2002, new foreign investor regulations were established where a $25 \%$ minimum reserve of the issued share capital was for locals while the balance of the $75 \%$ was a free float for all classes of investors. The $25 \%$ minimum reserve applies during initial public offerings (IPOs) and Government of Kenya privatizations (Ngugi, 2003).

\subsection{Base Broadening Hypothesis}

Base broadening hypothesis suggested that the expansion of the investors' base by including foreign investors would lead to increased diversification followed by reduced risk and thereafter lowering the required risk premium. The participation of foreign investors in the market brings about a demand shift and hence a permanent price change. Therefore, there is a permanent increase in the equity share price through risk pooling which is the signal of higher returns (Bodla \& Garg, 2007).

The theory was developed from the work of Merton (1987) who asserted that increasing the investor base for a given stock market could raise stock prices through risk pooling. Merton further suggested that investors only invest in stocks which they are well informed, meaning that if the local and informed foreign investors have the same information, they would be able to have the same selection of portfolios.

Okuyan and Erbaykal (2011) in their study, emerging from base broadening hypothesis, investigated whether the foreign transactions had an effect on the security returns in Instabul Stock Exchange. The cointegration relationship between two variables was analysed by the bounds testing approach and ARDL models using the monthly data of 1997-2009. As a result, a positive relationship was detected between the foreign transactions and returns of shares in the long run. The findings were interpreted as the validity of base broadening hypothesis in long term in Instabul Securities Exchange.

Henry (2000) examined stock market liberalization, economic reforms, and emerging market equity prices. Henry pointed out that a sudden change in investors' composition due to liberalization in emerging stock markets could influence the pricing of stocks. As a result of increased risk sharing and higher liquidity, prices would increase as a result of decrease in expected returns. To add up, as the securities of a given country are exposed to a larger number of investors, the required return for these securities decline leading to an increase in price.

Bekaert and Harvey (2002) analysed the effects of foreign investors trading in 20 emerging markets after market liberalization. They found permanent price which they claim to be evidence for the base broadening hypothesis. More specifically, they document that the cost of capital is reduced after markets are opened up to foreign investors. For the Turkish market, Adabag and Omelas (2004) found strong persistence in foreign flows, which suggests foreign investors change their market positions slowly enough to avoid sudden swings in prices, or excess volatility.

Clark and Berko (1997) studied foreign investment fluctuations and emerging market stock returns in Mexico and noted the beneficial effects of allowing foreigners to trade in stock markets by outlining the base-broadening hypothesis. Clark and Berko explained that the perceived advantages of base-broadening arise from an increase in the investor base and the consequent reduction in risk premium due to risk sharing.

\section{Methodology}

The study used causal research design which is more quantitative in nature as well as deliberate and configured design. Causal research design happen when variation in one incident, an independent variable, leads to, on average, a variation in another incident, the dependent variable (Delbert \& Neil, 2002).

The population of the study was 21 listed financial institutions in Kenya. Purposive sampling technique was used to select a sample size of 14 listed financial institutions whose monthly foreign data was available at Nairobi Securities Exchange for the period January 2008 to December 2014. The sample size of 14 listed financial institutions and the seven year period (January 2008 to December 2014) had been choosen on account of availability of monthly foreign data from NSE. The seven listed financial institutions that were left out were either listed later i.e. after 2008 or they were small in size hence inability to attract foreign investors resulting to lack of foreign data during the period of study.

Panel financial data for the seven year period that is January 2008 to December 2014 was used in the study to determine the effect of international portfolio equity purchases on security returns of listed financial institutions in Kenya. E-views software output was used to interpret regression coefficients. The study utilised secondary data 
which was collected from Kenya Bureaus of Statistics, Capital markets Authority, Central Bank of Kenya and Nairobi Securities Exchange.

Stock return as measured by changes in share prices is the increase in the price of a security over a period of time.

Foreign portfolio equity purchases is measured as changes in total monthly gross foreign equity purchases. When there is an increase in foreign portfolio equity inflows, the stock return is expected to go up according to positive feedback and price pressure hypothesis; hence a positive relationship is expected between international portfolio equity inflows and security returns.

Unit root tests were conducted using the Levin, Lin and Chu unit root test method to ensure that the variables had no unit roots.

A panel data regression using the Ordinary Least Squares method was adopted in this study where was pooled into a panel data set and estimated using panel data regression. Panel data is cross sectional time series data set that follows a given sample of individuals over time and hence resulting to multiple observations on each individual in the sample. Panel data is either balanced or unbalanced. A balanced panel data have some time periods for each cross - section observation while an unbalanced panel data has time dimension that is specific to each individual (Hsiao, 2003).

According to Wooldridge (2001) panel data has benefits. Panel data allows for a large number of data points, increasing the degrees of freedom and reducing collinearity among independent variables. Panel data also analyses a number of economic and financial issues that cannot be addressed using time series or cross- sectional data sets. Further, Panel data provides a way of resolving the magnitude of econometric problems that occur in empirical studies.

E-Views 7 data analysis software was used and the study hypotheses were measured using one panel data regression equation.

The following regression model was used to test the hypotheses

$$
S R_{i t}=\alpha+\beta_{1} F P E S_{i t}+\beta_{2} F P E P_{i t}+\beta_{3} F_{P E T_{i t}}+\beta_{4} E R R_{i t}+\beta_{5} \text { TBILit }+\beta_{6} I N F L_{i t}+\beta_{7} M C A P_{i t}+\mu_{i t}
$$

Where;

$S R_{i t}=$ Stock returns at time $t$,

$F P E S_{i t}=$ Foreign portfolio equity sales at time $t$,

$F P E P_{i t}=$ Foreign portfolio equity purchases at time $t$,

$F P E T_{i t}=$ Foreign portfolio equity turnover at time $t$,

$E R R_{i t}=$ Exchange rate risk at time $t$,

TBILit $=$ Treasury bill rate at time $t$,

$I N F L_{i t}=$ Inflation rate at time $t$,

$M C A P_{i t}=$ Market capitalization at time $t$,

$\alpha=$ The intercept,

$\beta_{i}=$ The parameter of explanatory variables of FPES, FPEP, FPET, ERR,TBIL, INFL and MCAP,

$\mu_{i}=$ The disturbance term.

\section{Discussion of Findings}

Table 1 presented correlation analysis results. All the variables were found to be stationary at intercept and level I (0) as per the unit root tests results. The Levin, Lin and Chu statistic for all the variables were significant at 1 percent level of significance therefore the null hypothesis that the variables have a unit root is rejected. The results are as shown in table 2. Panel estimation output results on for the effect of international portfolio equity purchases on security returns of listed financial institutions in Kenya are as indicated by Table 3.

The panel estimation output results indicated that international portfolio equity inflows had a coefficient of -0.000409 with a P- value of 0.9254 which is insignificant. The results a therefore means that international portfolio equity inflows have no effect on security returns. The findings tend to relate to the work of Pramod and Puja (2014) who examined the dynamics of the relationship between foreign institutional investment flow and security returns for India using daily data over the period of 2002 to 2012. Pramod and Puja concluded that foreign institutional investors (FIIs) inflow do not have any significant impact on market returns but the flows 
are significantly affected by their own lags and lagged returns, implying that they follow their own past strategy as well as the recent market behaviour.

Therefore, the null hypothesis stating that international portfolio equity inflows have no significant effect on security returns in Kenya's listed financial institutions fail to be rejected.

Table 1. Results for correlation

\begin{tabular}{ccccccccc}
\hline & SR & ERR & FPEP & FPES & FPET & INFL & MKTCAP & TBIL \\
\hline SR & 1.000000 & -0.112340 & 0.0000585 & -0.018749 & -0.022736 & -0.086402 & 0.031703 & -0.007254 \\
ERR & -0.112340 & 1.000000 & -0.027548 & -0.011439 & -0.047305 & 0.147806 & 0.039723 & -0.246422 \\
FPEP & 0.0000585 & -0.027548 & 1.000000 & 0.014468 & -0.010287 & -0.005791 & -0.006912 & 0.013711 \\
FPES & -0.018749 & -0.011439 & 0.014468 & 1.000000 & 0.086433 & -0.012357 & -0.015138 & -0.015804 \\
FPET & -0.022736 & -0.047305 & -0.010287 & 0.086433 & 1.000000 & -0.059813 & 0.016046 & 0.207902 \\
INFL & -0.086402 & 0.147806 & -0.005791 & -0.012357 & -0.059813 & 1.000000 & 0.000339 & -0.066905 \\
MKTCAP & 0.031703 & 0.039723 & -0.006912 & -0.015138 & 0.016046 & 0.000339 & 1.000000 & 0.001098 \\
TBIL & -0.007254 & -0.246422 & 0.013711 & -0.015804 & 0.207902 & -0.066905 & 0.001098 & 1.000000 \\
\hline
\end{tabular}

Table 2. Results for stationarity test

\begin{tabular}{lcc}
\hline VARIABLES & Levin, Lin and Chu Statistic (Intercept) & Level of Integration \\
\hline SR & $-39.3470(0.0000)^{* * *}$ & $\mathrm{I}(0)$ \\
ERR & $-22.2523(0.0000)^{* * *}$ & $\mathrm{I}(0)$ \\
FPEP & $-37.4225(0.0000)^{* * *}$ & $\mathrm{I}(0)$ \\
FPES & $-30.5492(0.0000)^{* * *}$ & $\mathrm{I}(0)$ \\
FPET & $-20.5634(0.0000)^{* * *}$ & $\mathrm{I}(0)$ \\
INFL & $-21.2828(0.0000)^{* * *}$ & $\mathrm{I}(0)$ \\
MKTCAP & $-43.3661(0.0000)^{* * *}$ & $\mathrm{I}(0)$ \\
TBIL & $-3.03863(0.0012)^{* * *}$ & $\mathrm{I}(0)$ \\
\hline
\end{tabular}

**Probabilities for Levin, Lin and Chu tests assume asymptotic normality.

*** Significant at $1 \%$ level of significance.

** Significant at $5 \%$ level of significance.

* Significant at $10 \%$ level of significance.

Table 3. Results from the panel estimation output

\begin{tabular}{|c|c|}
\hline \multirow[t]{2}{*}{ VARIABLE } & RANDOM EFFECTS MODEL \\
\hline & Coefficient (P-Value) \\
\hline \multirow[t]{2}{*}{ ERR } & -0.758983 \\
\hline & $(0.0002)^{* * *}$ \\
\hline \multirow[t]{2}{*}{ FPEP } & -0.000409 \\
\hline & $(0.9254)$ \\
\hline \multirow[t]{2}{*}{ FPES } & -0.002180 \\
\hline & $(0.5188)$ \\
\hline \multirow[t]{2}{*}{ FPET } & -1.029565 \\
\hline & $(0.4191)$ \\
\hline \multirow[t]{2}{*}{ INFL } & -1.435119 \\
\hline & $(0.0123)^{* *}$ \\
\hline \multirow[t]{2}{*}{ MKTCAP } & 0.007181 \\
\hline & $(0.2116)$ \\
\hline \multirow[t]{2}{*}{ TBIL } & -0.159235 \\
\hline & $(0.2492)$ \\
\hline \multirow[t]{2}{*}{$\mathrm{C}$} & 4.036005 \\
\hline & $(0.0024)$ \\
\hline R-Squared & 0.021380 \\
\hline Prob (F- Statistic) & 0.000672 \\
\hline Durbin- Watson Statistic & 2.375566 \\
\hline $\mathrm{N} \times \mathrm{t}$ & 1176 \\
\hline
\end{tabular}




\section{Summary of Findings}

The results from panel estimation output indicated that international portfolio equity inflows had a coefficient of -0.0004 with a P-value of 0.9254 which is insignificant. The results indicated that international portfolio equity inflows have no effect on security returns. Therefore, the null hypothesis stating that international portfolio equity inflows have no significant effect on security returns in Kenya's listed financial institutions fail to be rejected.

\section{Conclusion}

The study found out that international portfolio equity inflows have no effect on security returns. The study concluded that financial institutions should device ways of attracting foreign portfolio equity inflows as they improve the liquidity position of this firms although they don't affect security returns.

\section{Recommendation}

Although international portfolio equity inflows have no effect on security returns in NSE listed financial institutions in Kenya, policies that attracts international portfolio inflows ought to be implemented so as to increase liquidity and encourage the stability of security returns.

\section{References}

Adabag, M. C., \& Ornelas, J. H. (2004). Behaviour and effects of foreign investors on Instabul stock exchange. Working paper, SSRN.

Bekaert, G., \& Harvey, C. R. (2002). Foreign speculators and emerging equity markets. Journal of Finance, 55, 565-613. https://doi.org/10.1111/0022-1082.00220

Bodla, B., \& Garg, A. (2007). The impact of foreign institutional investors on underlying stock market. Journal of Finance, 4(1), 56-63。

Capital Markets Authority. (2013). Quarterly statistical bulletins. Nairobi.

Clark, J., \& Berko, E. (1997). Foreign Investment Fluctuations and Emerging Market Stock returns. Staff Reports No. 24, Reserve Bank of New York.

Delbert, C. M., \& Neil, J. S. (2002). Handbook of Research Design and Social Measurement (6th ed.). London: Sage Publication.

Henry, P. B. (2000). Stock market liberalization, economic reforms, and emerging market equity prices. Journal of Finance, 55(2), 529-564. https://doi.org/10.1111/0022-1082.00219

Hsiao, C. (2003). Analysis of Panel Data (2nd ed.). Cambridge University Press. https://doi.org/10.1017/CBO9780511754203

International Monetary Fund. (2011). Recent experiences in managing capital inflows- cross cutting themes and possible framework. IMF policy paper.

Merton, R. C. (1987). A Simple Model of Capital Market Equilibrium with Incomplete Information. Journal of Finance, 42, 483-510. https://doi.org/10.1111/j.1540-6261.1987.tb04565.x

Ngugi, R. W. (2003). Development of the Nairobi Stock Exchange: A historical perspective (Discussion paper No. 27). Nairobi: Kenya Institute for Public Policy Research and Analysis.

Okuyan, H. A., \& Erbaykal, E. (2011). The relationship between foreign investment and stock returns in Instabul Stock Exchange. Journal of International Finance, 12(2), 256-264.

Pramod, K. N., \& Puja, P. (2014). An Empirical Evidence of Dynamic Interaction between institutional fund flows and Stock Market Returns. Munich Personal Archive. Retrieved November 19, 2015 from http://mpra.ub.uni-muenchen.de/57723/

Ren, M. (1997). International portfolio flows and security markets. Harvard Business School.

Wooldridge, J. M. (2001). Econometric analysis of Cross section and Panel data. The MIT Press.

\section{Copyrights}

Copyright for this article is retained by the author(s), with first publication rights granted to the journal.

This is an open-access article distributed under the terms and conditions of the Creative Commons Attribution license (http://creativecommons.org/licenses/by/4.0/). 